\title{
Slave rebellion during the Age of Revolution
}

\author{
David Geggus
}

Violent rebellion punctuated the history of African American slavery from its beginnings, but it was apparently never more prevalent than during the Age of Revolution. Although no one to my knowledge has attempted a complete census of slave revolts and conspiracies in the New World, it would seem that the decades from the 1770 s to the 1840 s witnessed the largest, the best known, and most frequent, both in Brazil and North America, as well as in the Caribbean heartland of American slavery. Within this timeframe, the 1790s stand out as a period of peak intensity, and the single year 1795 may be unique for its number of separate incidents in different societies. The slave insurrection in western Curaçao in the summer of that year, and its unusual sequel of five years later, ${ }^{1}$ thus occurred in the midst of a broad wave of rebellion that challenged the institution of slavery in an unprecedented manner. Its significance, aims, and ultimate impact remain controversial.

\section{DEFINITIONS AND DATA}

It is not obvious at what point a collective act of violence merits the label 'slave rebellion'. In his pioneering study of United States rebellions, Herbert Aptheker applied a minimum criterion of ten participants. I have not done so here, as such information often lacks historical sources. The listing offered in the appendix to this chapter is therefore somewhat imprecise as well as undoubtedly deficient in coverage. As the case of Curaçao illustrates, African American rebellion took several forms in this period. The most massive and lengthy conflicts tended to be those in which emancipated slaves resisted attempts to reenslave them - as in St. Lucia,

1 See the chapters by Oostindie and Jordaan in this volume. 
1795-97, in Saint-Domingue after 1793, and Guadeloupe in 1802 or multi-class rebellions like those on Grenada and St. Vincent in 1795, which involved slaves but were dominated respectively by free men of colour and Black Caribs. For analytical purposes, I think it is important to distinguish such events that made use of organization, experience, and weaponry available only outside the state of slavery from revolts and conspiracies in which enslaved persons were the most important participants, on which I focus in this chapter.

The upheaval of summer 1800 in Curaçao (that involved French Caribbean troops and a variety of local actors) is one instance among several that pose problems of definition. Since slaves neither initiated nor directed the events, it could be termed a multi-class rebellion. Yet, as Han Jordaan shows in this volume, participation by the local free population was very limited. I have hesitantly classed it as a slave rebellion because most participants were slaves and it seems to have involved the autonomous participation of most of the slave population (Jordaan 2011; Palacios 1983:20-7). The fact that the French were not trying to free the slaves only underlines the autonomy of the slaves' actions. ${ }^{2}$ Borderline cases that I would exclude from the category of slave rebellion are the 1802 and 1808 mutinies on Dominica and Jamaica of African soldiers serving in the $2^{\text {nd }}$ West India regiment; the successful campaign of the Cobreros community in eastern Cuba to be recognized as free (that took a violent turn in the banner year 1795), and attacks on or by established maroon communities, which were quite common in Brazil and in the early United States. The revolt of Jamaica's Trelawny Maroons in 1795 clearly should not be confused with a slave rebellion since all the insurgents were born free. ${ }^{3}$

As for slave conspiracies that did not progress to the stage of rebellion, the main problem for historians remains that of the slaves' contemporaries: were the plots real or imaginary? If Robert Paquette's study of Cuba's 'Escalera' conspiracy of 1843 has largely removed former doubts about its authenticity, Michael Johnson's research suggests that Denmark Vesey's much-studied conspiracy in Charleston, South Carolina, may well have been a fantasy manufactured by Vesey's white interrogators (Paquette 1988; Johnson 2001:915-76). Herbert Aptheker's pioneering survey of U.S. slave resistance has been much criticized for using flimsy sources; I have relied on it and Guillermo Baralt's book on Puerto Rico selectively (Aptheker 1943; Genovese 1986:24-25).

2 The French invaders informed the Dutch administration they would not interfere with slavery (Goslinga 1990:30).

3 The wars fought by the maroons of Dominica in 1809-1814 or by the Boni in Suriname (1789-1793) were different but not sufficiently so to qualify as slave rebellions. 
A limited sampling of limited sources, the listing of roughly 180 incidents presented in the appendix should be understood as no more than a minimum tally. It no doubt underrepresents Brazil and Cuba. ${ }^{4}$ The fact that revolts are slightly more numerous than conspiracies in the historical record may reflect the vagaries of news dissemination and record-keeping rather than slaves' behavior, and the rough parity between Brazil (27 incidents) and the United States (25 incidents) assuredly is due to the latter's greater supply of local newspapers. The prominence of Caribbean societies is nonetheless as expected. Although only half of American slaves lived in the Caribbean in 1790 and less than a third by 1830 , the region's pronounced imbalance between slave and free and its focus on sugar cultivation both facilitated and provoked a higher level of violent resistance than elsewhere.

This regional discrepancy is magnified when we take into account the size of the rebellions. Although the Bahian insurrections commonly mobilized hundreds of slaves, and the details of the Venezuelan conflict of 1811-1813 remain unclear, no mainland rebellion appears to have involved more than 1,000 slaves. In North America, only the 1811 revolt in the Louisiana territory mobilized more than 100 slaves. Yet, in the West Indies and Guianas there were, even if we count Saint-Domingue 1791-1793 as one case, no fewer than eight or nine rebellions that involved at least 1,000 slaves. It is extraordinary that tiny Curaçao accounts for two of these eight or nine cases.

To be sure, such numbers are very approximate, and in the largest cases historians tend to shift from counting armed men to estimating the total number of slaves living in areas controlled by rebels. Even within the Caribbean group of slave rebellions, clearly we are dealing with a very disparate array of events. Even if Jamaica's Christmas Rebellion of 1831 mobilized 18,000 slaves (as per Anthony Synnott) rather than 60,000 (as per Michael Craton), it would have included half of all the slaves who ever rebelled in the British Caribbean. ${ }^{5}$ As for Saint-Domingue, not only did the Northern Plain uprising of 1791-1793 dwarf all others in magnitude, duration, and outcome, but it stimulated five or six other revolts in different parts of the colony that each involved probably thousands of insurgents. ${ }^{6}$

4 Yacou (1984:48), claims Cuban revolts numbered 'une soixantaine' between 1833 and 1843 , but gives no details. Bahia has been studied more than other Brazilian provinces.

5 Synnott 1976:270; Craton 1982:291. This excludes the $4<6,000$ slaves who joined the 1795 multi-class rebellion on Grenada.

6 Léogane/Jacmel (early 1792); Cul de Sac plain (early 1792, early 1793); Anse-à-Veau 1792; Cayes plain 1792; and perhaps the Artibonite plain (1792-93). 
This much greater incidence of large-scale rebellions in the Caribbean may be attributed partly to the demographic imbalance mentioned above and the region's larger average plantation size, which facilitated mobilization, and partly to the destabilizing political influences that marked the Age of Revolution and were particularly severe in the region.

\section{DEMOGRAPHY}

Before considering those political influences, let us note the obvious fact that one reason that rebellions and conspiracies were numerous and large between 1776 and 1848 was because there were more people in the Americas living in slavery than ever before or there would be again. At 3 million, the American slave population in 1790 was roughly twice what it had been fifty years before, and it would almost double again during the next half-century, despite the ending of slavery in Haiti and the British colonies (Engerman and Higman 1997, III:45-104). This explanation, however, only goes so far. The incidence of slave rebellion seems to drop off considerably after 1848, while the slave population did not do so until the 1860s.

More to the point perhaps, these were the peak years of the Atlantic slave trade. There is a strong correlation between mass arrivals of enslaved Africans and the incidence of rebellion in Bahia (1800-1830), Central Brazil (1835-1850), and Cuba after 1795. The same can be said of Louisiana during the decade before the large 1811 uprising, and of Saint-Domingue on the eve of the Haitian Revolution, when the colony was breaking all previous records for the Atlantic slave trade. The white proportion of the Cuban and Brazilian populations shrank in the early nineteenth century, and the enslaved proportion of the Caribbean population probably reached its greatest extent (70 percent) in 1790 .

Two caveats should be noted. For the British colonies, there is no obvious relationship between the slave trade and slave rebellion in these years, and the three 'late' rebellions there, on creolized Barbados (1816), Demerara (1823), and Jamaica (1831), seriously undermine any attempt to correlate slave rebellion with an African presence. Similarly, while the vertiginous growth of SaintDomingue's slave trade in 1785-90 almost makes the 1791 uprising look like a product of demographic determinism, the revolt in fact broke out in the most creolized part of the colony and was led largely by locally born slaves; the most African parts of SaintDomingue were the slowest to join the Haitian Revolution. Hence 
we should not be surprised if the two major rebellions in Curaçao's history took place when its slave population was already highly creolized.

The central question raised by this clustering of rebellions and conspiracies by black slaves is what connection they might have with the white Atlantic's Age of Revolution. In his grand survey of slave resistance in the United States, Herbert Aptheker remarked that the spread of progressive ideas in the Western world, including abolitionism, and news of foreign rebellions were among the background influences on American slave revolts around the turn of the nineteenth century, but the causal factors he stressed most were recurrent economic depression and the rapid growth of the slave population. Michael Craton, a historian of the British Caribbean, thought a new type of rebellion emerged in these years, but he attributed it to the creolization of the slave population, positing 'African' and 'Creole' types of rebellion (Craton 1979:99-125, 1980:1-20).

Eugene Genovese put forward a different type of schema, hemispheric in scope, that made libertarian ideology the active agent. Seeking to write American slaves into the making of modernity, Genovese maintained that, whereas early slave insurgents sought seclusion and accepted the enslavement of others, the French Revolution gave rise to a new revolutionary type of slave uprising that sought liberty for all and engagement with the wider world (Genovese 1979:xviii-xxii, 82-125). The main weakness of this thesis is that Genovese failed to provide any plausible examples of the new type of insurrection apart from the Haitian Revolution and the Coro rebellion (Geggus 1989:122, 2002:66-7). Instead of straining to include Nat Turner and Denmark Vesey, and using inaccurate descriptions of events on Trinidad and Jamaica, he could have strengthened his case with mention of the 1795 rebellion on Curaçao.

More recently, historians have shown greater interest in exploring the impact of the Haitian Revolution in its own right. Separating the two intertwined revolutions, French and Haitian, is somewhat arbitrary: the metropolitan revolution initiated the colonial one and, in turn, the conflict in Saint-Domingue forced antiracism and antislavery on to the agenda of the revolution in France. However, if the French Revolution proclaimed the ideals of liberty and equality, the Haitian Revolution demonstrated to colonized peoples that 
they could be won by force of arms. Plantation societies built on bondage, prejudice, and inequality were peculiarly vulnerable to the ideology of revolutionary France, but the dramatic example of self-liberation offered by Saint-Domingue's transformation into Haiti brought the message much closer to home. On the other hand, once the French Republic had adopted slave emancipation, it took a more active approach to exporting this policy than did black revolutionaries in Saint-Domingue.

Finally, we need to consider the influence on slave insurgents of the antislavery movement that became a political force in the years between the American and French revolutions and by 1848 had freed many more slaves than did the Haitian Revolution. Although abolitionism became incorporated into the French and Haitian revolutions, it was an autonomous movement that pre-dated and outlasted them, and it was more directly relevant to slaves than libertarian ideology. It was far more influential in the Anglophone world than elsewhere, but even where it was least successful, in the Spanish empire, it had an influence on slave resistance.

Unlike the social changes singled out by Michael Craton, or the local traditions of resistance that Haitian historians often emphasize as the main cause of their revolution, the focus on abolitionism or foreign revolutions as a major influence on slave resistance elevates external over internal causes and shifts attention to the circulation of people, news, and ideas that is central to the growing popularity of the Atlantic approach.

\section{THE AMERICAN REVOLUTION}

Of all the Atlantic revolutions, the American Revolution evidently had the least impact on slavery, although many thousands of slaves were able to take advantage of the conflict to escape their bondage, and its aftermath brought about the abolition of slavery in states where it was of marginal importance, like Massachusetts and Pennsylvania (Quarles 1961; Schama 2005). After the revolution, many slaves and freedmen were transplanted to the Caribbean from North America. Thomas Benjamin has suggested that they or other African American soldiers who fought in the war may have played a role in the wave of slave rebellion that swept the West Indies in the 1790 s, but there is no evidence of this. ${ }^{7}$ However, there are several other possible linkages about which we can speculate. First, it is

7 Benjamin 2009:587. The author confuses slaves with free men of colour. 
worth pondering how Caribbean slaves received the news of the northeastern emancipation acts, which, after all, mark the beginning of the end of slavery in the Americas. Given the strong maritime links between Philadelphia and New England and the West Indies, and the prominence of black sailors in that trade, it would be surprising if news of this first legislative assault on slavery did not reach the ears of Caribbean slaves and help shape what Julius Scott has termed a 'culture of expectation' (Scott 1986:122, 158). Second, there is the example set by Governor Dunmore of Virginia, who in 1775 recruited slaves with offers of freedom to fight for the crown against their Patriot masters. Did the Saint-Domingue insurgents of 1791 have this model in mind when they claimed to be fighting for the king? When Dunmore was a dinner guest of Plaine du Nord planters in 1789, his wartime experiences were assuredly a topic of dinnertime conversation (Geggus 1997b:9, 36 n43). Lastly, the surprising fact that Afro-Cuban revolutionary José Antonio Aponte possessed a portfolio of pictures that included George Washington, as well as Jean-Jacques Dessalines and Toussaint Louverture, and that the U.S. slave leader Gabriel also supposedly invoked Washington's example, suggests that the American Revolution served as an object lesson for slaves as well as others that power could be successfully contested (Childs 2006:3, 28; Sidbury 1997:261).

\section{THE FRENCH REVOLUTION}

The ways in which the French Revolution encouraged slaves to contest their enslavement are varied. Apart from the libertarian ideology that enflamed aspirations and exacerbated the sense of injustice, the revolution directly weakened colonial power structures by dividing their free populations into hostile factions, creating military mutinies, and undermining traditional authority, thus creating opportunities that slaves could seize. Chiefly affected in this manner were the French colonies, which dominate the record of slave resistance during the period 1789-93. When the French Republic finally abolished slavery in February 1794, a new, more international phase began in which slave emancipation became, for a few years, a weapon of war aimed primarily at Britain's colonies. More specific ramifications of the Republic's foreign policy also encouraged slaves to rebel when it seemed likely that the formerly French colonies of Louisiana and Tobago might be retroceded to France (in 1795 and 1801 respectively), and when the French occupied the United Provinces, so providing one of the justifications for Tula's rebellion in Curaçao. 
The impact of libertarian ideology is the most difficult connection to prove. At first sight, it may seem the most obvious, but slave insurgents in the French Caribbean rarely deployed a language of rights. They usually claimed that they had already been freed - by the king, in Martinique and Saint-Domingue, or by the National Assembly, in Guadeloupe. The slave leaders in northern Saint-Domingue, including Toussaint Louverture, combined an ostentatiously royalist rhetoric with rather flexible demands as to how many slaves should be freed, until the radical (and abolitionist) French commissar Sonthonax ended slavery there in August 1793. The evidence that slaves used the term 'rights of man' is actually quite limited, and in large measure derives from a document that is almost certainly a forgery (Geggus 2006:297314, 2001:109-16).

Far easier to show is the way the French Revolution materially weakened slaveholding regimes. The moment chosen for their uprising by the northern plain insurgents of 1791 coincided with the onset of a civil war between whites and free coloureds and followed shortly after the deportation of half of the colonial garrison. The insurgents astutely exploited divisions between white radicals and conservatives, as did their counterparts in Guadeloupe in 1793. In Dutch Demerara, much as in Curaçao, the slaves rebelled in 1795, taking advantage of conflict between pro- and anti-French factions in the ruling class, and fighting against both. ${ }^{8}$

The Republic's abrupt adoption of abolition in February 1794 belatedly fused libertarian politics and antislavery, and united the movement for black self-liberation with the resources of a major power. The chief result of France's decision to use this policy against its enemies was the series of multi-class risings in the British Windward Isles supported by Victor Hugues in Guadeloupe and Commissaire Goyrand in St. Lucia. The Coro rebellion, the same year, would seem to be another example, in view of the shadowy presence of French privateers off the Venezuelan coast, and the insurgents' apparent call for a republic and 'la ley de los franceses' (Brito Figueroa 1961:60-79, 103-4). This interpretation has been challenged, however, by historians who imply that local Spanish officials emphasized a French connection in order to cover up their oppressive behavior that was the real cause of the insurrection (Aizpurua 1988:705-723; Rivas, Dovale Prado and Bello 1996:10325). Certainly, the sudden wave of rebellion that affected the Spanish empire in 1795, from Buenos Aires to Louisiana, suggests that

8 Craton 1982:272. However, the events in Demerara might better be described as slave cooperation with maroon attacks than an actual revolt. 
internal factors like the gracias al sacar law passed that February, increases in sales tax, and the withdrawal of a new slave code at the end of 1794 were important in mobilizing resistance independent of any foreign influence.

The blacksmith Gabriel's ambitious conspiracy in Richmond, Virginia, in 1800 appears very much a response to the abolitionism of the French Republic. France was then unofficially at war with the United States, and local Frenchmen reputedly played a role in the plot. Historians often link the conspiracy to the Haitian Revolution, but contemporary sources show no trace of the conspirators' discussing Saint-Domingue, and evidence of the black revolution's impact on Virginian slaves is in fact remarkably slight. ${ }^{9}$ The attempt launched from Saint-Domingue in 1799 to foment a slave insurrection in Jamaica was similarly a French rather than a 'Haitian' venture. The initiative came from Paris, and it was organized by the local French official Philippe Roume, not the black governor Toussaint Louverture. Toussaint, indeed, secretly revealed the plan to the British, and the French emissaries were captured (Debien and Pluchon 1978:3-72). This ironic clash between the French and Haitian revolutions was due to Toussaint's need to avoid a maritime blockade by the British, which meant he could not afford a policy of exporting slave insurrection.

\section{THE HAITIAN REVOLUTION}

This decision to settle for 'a revolution in one country' and to avoid foreign entanglement became the policy of independent Haiti and was announced in its declaration of independence in 1804. The Haitian Revolution's contribution to slave rebellion elsewhere was therefore very rarely a matter of direct assistance. One example is provided by the south coast privateers, part-French, part-Dominguan, who attempted to launch a rebellion in Maracaibo in 1799, and who may have played the same role in Coro four years before (Helg 2001:159-60). As they were acting against their French officers' wishes, they represent another divergence of the Haitian from the French revolution, this time in favor of propagating slave rebel-

9 See, for example, Sidbury 1997:42-3, where the author claims as 'clear evidence' of the Haitian Revolution's influence a letter supposedly written by a black conspirator, although he notes the letter does not mention Saint-Domingue, that a white contemporary who linked it to the Caribbean did so without apparent justification, and that the conspiracy may not have existed. The letter, found dropped in the street in 1793, was probably a hoax. Even less evidence is offered in Douglas Egerton 1993 
lion. ${ }^{10}$ A similar case was Alexandre Pétion's somewhat accidental participation in the 1800 landing on Curaçao along with other refugees who had been driven from southern Saint-Domingue by Toussaint Louverture. ${ }^{11}$

If we juxtapose these events, both launched from the southern region of Saint-Domingue that was dominated by the free man of colour André Rigaud, with Alexandre Pétion's later assistance to Francisco Miranda in 1806 and to Simón Bolívar in 1816 (Verna 1969:87-298), it appears that attitudes to the propagation of revolution overseas varied among Haitian revolutionaries between the exslave leaders based in the north province and the anciens libres of the Bande du Sud. It was the freeborn men of mixed racial descent who sought to internationalize the revolution, not the former slaves.

More common were those revolts and conspiracies where we can show that insurgents drew inspiration rather than material help from the revolution in Saint-Domingue or from later events like the coronation of King Christophe in 1811. Surely the most remarkable case is the conspiracy, begun soon after the coronation, in Havana by the black carpenter José Antonio Aponte, who drew pictures of revolutionary leaders as a consciousness-raising exercise (Fischer 2004:41-56). Five years earlier, slaves on plantations around Havana, led by two creoles, had plotted to seize the city's forts so they could become free 'like those in Saint-Domingue' and 'absolute masters' of the land (García 2003:34-9). In 1796, African slaves planning a rebellion on a plantation in Spanish Santo Domingo sought advice from some Saint-Domingue insurgents who had settled nearby. Three years before, another conspirator in Santo Domingo, this time a creole, told his companions they were 'ass-holes' for doing nothing while blacks were killing whites in Saint-Domingue (Geggus 1997a:131) . In 1816, on Barbados, the elderly Nanny Grigg advised conspirators to 'set fire the way they did in St. Domingo' (Craton 1982:261).

In several instances, we find insurgent slaves expecting 'Haitian' help, sometimes because manipulative leaders had assured them it would be forthcoming. Apparently a confidence-boosting device, it shows up in the Curaçao rebellion of 1795; in the Vesey plot in Charleston; in Puerto Rico in 1841; in Havana, in the 1843 Ladder conspiracy and the 1811 Aponte conspiracy, and also in Santo Domingo in 1811, in the multiracial conspiracy of Manuel

10 French policy distinguished between the colonies of its enemy, Britain, and those of its allies, Spain and the Batavian Republic.

11 This followed the War of the South (1799-1800), in which Toussaint defeated André Rigaud and took over southern Saint-Domingue. Pétion later became Haiti's first president. 
del Monte. In Curaçao, the slave leader Tula not only claimed to be in contact with the Dominguan revolutionary André Rigaud, whom the French Republic had promoted to general a few months before, but he also adopted his name. In the Aponte conspiracy a free black actually pretended to be the Dominguan slave leader Jean-François. ${ }^{12}$

Another category of rebellions and conspiracies consists of those that involved Francophone slaves or men of colour, known or presumed to have come from Saint-Domingue or Haiti, and therefore to have been witnesses of the revolution there. Tula's rebellion on Curaçao is a striking example, one of its participants declaring 'Nous sommes ici pour vaincre ou mourir'; so is the 1811 insurrection in Louisiana led by the slave driver Charles Deslondes, which was the largest in North American history (Hartog 1961, I:327; Paquette 1997:218-20). Less well known is the aborted revolt at St. Pierre, Martinique, the same year, whose leader had served in the Haitian army and had links to Haitian expatriates on Curaçao (Geggus 1996: 127-30). Cuba provides many other examples, from 1795 down to the Ladder conspiracy in 1843; Louisiana, another example in 1795; the Bahamas and Jamaica, two cases each; and Puerto Rico, Cartagena, and Marie Galante one case each (Geggus 1997b:14, 40 n79, 2003:43-7). Both the Coro rebellion's main leaders, Chirinos and González, were said to have visited SaintDomingue. ${ }^{13}$

Some historians have claimed a Haitian influence on rebellions where evidence seems to be lacking. ${ }^{14}$ And contemporaries also disagreed sometimes. When Bahian planters, after a large rebellion in 1814, claimed that local slaves were discussing the Haitian Revolution, the local governor claimed that the planters were making this up in order to force him to adopt more draconian measures of control (Reis and Gomes 2009:289). In Jamaica, unfounded rumors regarding French and French Caribbean agents abounded at the time of the Second Maroon War (Geggus 1987:280-3). However, there is a methodological or epistemological issue here. Some may feel it beyond question that the unprecedented success of SaintDomingue's black rebels inevitably played a major role in motivat-

12 Oostindie this volume; Geggus 2003:43-7. By a strange coincidence, Rigaud's brother Joseph later participated in the 1800 invasion of Curaçao, where he was executed: Pauléus Sannon 1920, II:199.

13 According to Brito Figueroa 1985:225, Chirinos travelled 'constantly' to Saint-Domingue. However, only one visit (with his white employer) is reported in Documentos 186.

14 For example, the claims, found in 1997:85 and Langley 1996:141 that, respectively, Jamaica's Christmas Rebellion and the Malé Revolt in Bahia were Haitian-inspired. On Virginia, see above, note 9 . 
ing subsequent resistance, and where written evidence is lacking, it must be due to the arbitrariness of colonial document-making.

There is little doubt that news of the Haitian Revolution traveled wide and fast from its opening moments. By September 1791, Jamaican slaves were singing songs about it, and blacks in Havana were believed to be sacrificing pigs in honor of the insurgents. When Toussaint Louverture occupied Santo Domingo in early 1801, slaves in the hills above Coro, in western Venezuela, were singing his praises within weeks (Geggus 2003:40-42; (pigs) Ferrer 2008:28). The year after Haiti achieved independence, supposed conspirators in Trinidad are recorded as parodying the Catholic mass, 'The bread we eat is white man's flesh. Remember St. Domingo!' ${ }^{15}$ The apparent propensity for Curaçao blacks to sing French revolutionary songs, both at home and abroad (as in La Guaira) seems more unusual (Hartog 1961, I:327; Edsel 1989:61-8).

News, however, did not travel as far and fast as some have suggested. Although Kenneth Maxwell quotes a visitor to Rio de Janeiro in 1792 as writing 'the secret spell that caused the Negro to tremble at the presence of the white man [had been] in a great degree dissolved' by the spectacle of 'black power', the quotation in fact dates from 1806 and applied to the whole of the Americas (Maxwell 1973:218; Barrow 1806:117-8). Free black and mulatto militiamen in Bahia were found to be wearing medallion portraits of Jean-Jacques Dessalines in 1805, a few months after he had been crowned emperor of Haiti. ${ }^{16}$ It is significant, however, that these were freemen, not slaves. Stuart Schwartz comments that there is nothing to link the long cycle of Bahian slave revolts in the period 1807-35 to either the Haitian or French revolutions, and that such external influences were much more visible in the case of free men (as in the 1798 Tailors' conspiracy) than of slaves (Schwartz 1986:468-88). The same can be said of the mainly African slave uprisings of nineteenth-century Cuba, and in the Caribbean more widely (Geggus 1989:109; Tardieu 2003:101-11).

THE ANTISLAVERY MOVEMENT AND REFORMISM

In the British colonies, autonomous slave rebellion reached something of a low point during the period of the French and Haitian

15 Brereton 2006:128-9. Brereton points out, however, that the sole source for this story dates from more than eighty years after the event.

16 Luiz Mott 1982:5. They are inadvertently described as slaves in Reis 1993:48. 
revolutions, but then rebounded. During the fifteen years following the Napoleonic War the British Caribbean produced three of the largest slave revolts in New World history: in Barbados (1816), Demerara (1823) and Jamaica (1831) (Craton 1982:254-321). The timing of each was quite clearly connected with successive developments in the antislavery movement in Britain. In each case, the insurgents demanded enforcement of an abolition law that they claimed (wrongly) had been passed by the imperial government but was being covered up by local authorities. From 1789 to the early 1830 s, there were more than twenty such rebellions and conspiracies in which slaves argued that they had already been freed by law (or that their workload had been reduced to three days a week). Such rumours also surfaced in several places without provoking resistance (Geggus 1997b:7-11).

The phenomenon was not confined to slave societies, and it was probably rooted in wishful thinking, a desire to believe in the beneficent intentions of the powerful, which on some occasions was clearly manipulated by astute leaders. Earlier examples can be found in the Americas, especially in the 1770s (Geggus1997b:35 n33; Schwartz 1986:478). However, beginning with an aborted rising on Martinique in August 1789, the syndrome appeared in a swift succession of revolts and conspiracies that were apparently linked to the emergence of antislavery movements in England and France and to recent government efforts there and in Spain to reform slavery or the slave trade. Such reform efforts and the slaveholders' hostile reaction to them were easily misinterpreted. Rumours of an official liberation that was being covertly sabotaged suggested to slaves that they had potential allies and obviously exacerbated the sense of injustice that Barrington Moore isolated as a crucial stimulant to rebellion (Moore 1978). Such rumours perhaps resonated more strongly with the enslaved than the concept of abstract rights emanating from revolutionary France, where abolitionism made little progress until 1793. Even Tula on Curaçao in 1795 seems to have justified his rebellion with reference to the French abolition decree (and a Christian egalitarianism) rather than to libertarian ideology (Goslinga 1990:10).

The first spate of these rumour-inspired revolts and conspiracies numbered nearly a dozen in the period 1789-93. They affected British, French, and Spanish colonies, and included the great uprising in northern Saint-Domingue. Another, smaller spate occurred in 1795 in the Spanish empire, where the withdrawal of the controversial Código Negro in late 1794, and reforms regarding free people of color contributed to a wave of resistance that stretched from Louisiana to Buenos Aires. After an isolated conspiracy involv- 
ing Brazilian slaves in the lowlands of Upper Peru (Bolivia) in 1809, more cases appeared in each of the Spanish Antilles and in Martinique in the period 1811-1812. This time the impulse seems to have derived from the Cortes of Cádiz, where a deputy proposed in 1811 to end slavery in Spain's colonies. In one district of Puerto Rico, however, the emancipation rumour became confused with news from Haiti, and Henry Christophe was perceived as the liberating monarch (Geggus 1997b:8, 10-11; Baralt 1985:27).

A similarly hybridized rumour sparked a slave conspiracy in Maranhão, north-east Brazil in 1827. On this occasion, it was said that British liberators would invade the region on behalf of the King of Congo (Röhrig Assunção 1999:23). In 1841, in Ponce on Puerto Rico's south coast, plotters expected help from both Haiti and from abolitionists, as did many of the Escalera conspirators two years later in Cuba (Baralt 1982:93; Paquette 1988:238, 242, 254). Finally, some historians believe that the Missouri debates of 1820 on limiting slavery's expansion in the United States and an attempt to end slavery in Kentucky in 1829 were among the stimuli that set in motion the Vesey plot of 1822 and the Nat Turner rebellion of 1831 (Aptheker 1943:270, 292).

\section{OTHER THEMES}

(1) Changing Tactics. According to Michael Craton, rebellions dominated by locally born creole slaves tended to be less violent than earlier ones led by Africans. Although they usually led to violence, it seems their leaders intended them to begin as work strikes in which the slaves could bargain from a position of strength (Craton 1979:99-125, 1980:1-20, 1982:291). Craton had in mind the last decades of British Caribbean slavery, but earlier examples can be found: in Martinique (1789), Dominica (1791), Guadeloupe (1793), Buenos Aires (1795), and Curaçao (1795), as well as later ones, in Martinique and St. Croix in 1848. These changing tactics obviously reflected changing expectations among the enslaved and the belief that governments were already willing to end slavery.

(2) Troop Levels. For American slave societies, much of the Age of Revolution was a period of warfare. War does not appear to have facilitated slave rebellion unless a belligerent party specifically encouraged it, as in Venezuela in 1811-1813, or Bahia in December 1822. In fact, wars probably made rebellions less likely. Sometimes they provided a safety valve by making it easier for slaves to run away, as in the American Revolutionary War, or they freed restless 
young males through the recruitment of slaves as soldiers, as in the long Spanish American conflict. Above all, they often they made rebellion more difficult because of their mobilization of large numbers of armed men. João Reis made this argument about the lack of major slave revolts in Brazil during its separation from Portugal (1821-1823), and the dearth of autonomous slave rebellions in the British Caribbean during the French Revolutionary and Napoleonic Wars can be attributed to the islands' exceptionally large garrisons during those years (Reis 1988:122; Geggus 1987:292-8). The incidence of slave resistance in Cuba in the same period also seems to have been influenced by war but in a reverse manner. Garrisons dwindled during periods of maritime war that made it difficult for Spain to reinforce them, and rebellion increased. Rebellion tended to diminish when the garrison was reinforced, as in 1799-1803, and 1813-1824 (Geggus 1997b:7 n31).

Apart from these general patterns, many individual rebellions or conspiracies occurred following a recent decline in the strength of the local garrison. This is true of the three large British Caribbean revolts of 1816, 1823 and 1831, and of the Saint-Domingue uprising of 1791. The Aponte conspiracy in Cuba also was launched when island troop levels were at a low point. Jamaica, Tobago, Santo Domingo, and Venezuela provide other examples (Geggus 1987:294-7, 2009:8). And one of the reasons the Virginia blacksmith Gabriel organized his conspiracy in 1800 was the opportunity provided by a reduction in the number of Federal troops as the Quasi-War with France came to an end (Aptheker 1943:225). Curaçao's garrison was always small and, given the difficulty of sending out new recruits during the 1790 s, it would not be surprising if it, too, was unusually weak in 1795 and $1800 .{ }^{17}$

(3) Free Coloured Involvement. A final way in which to compare acts of slave rebellion in this period is according their degree of free coloured participation, which was widespread but varied. Denmark Vesey was the only free man involved in the 1822 conspiracy he supposedly organized, but free men of African descent made up two-fifths of the planners of Venezuela's Coro rebellion, and Indians a tenth (Dominguez 1980:56). According to Jean-François, leader of the Saint-Domingue slave uprising, some two percent of his insurgent army consisted of free blacks and mulattoes (Geggus 2002:179). The rapid growth of free populations of colour around the turn of the nineteenth century probably explains why so many of these revolts and conspiracies involved free non-whites.

17 In 1801 the garrison numbered just 230, mainly German mercenaries described as 'unmotivated and unreliable' (Hartog 1961, I:495). 
Usually, as in Curaçao, where a couple of free blacks administered oaths to slave insurgents (Hartog 1961, I:325-6), ${ }^{18}$ free participants were neither numerous nor played prominent roles. Even so, several of the most salient events had free black leaders, like the carpenters José Antonio Aponte in Havana and Denmark Vesey in Charleston, or the sharecropper José Chirinos in Coro. Manuel Barcia, in fact, argues that both the Aponte and Escalera conspiracies were so dominated by freemen they were not slave conspiracies at all (Barcia 2008:46). In Saint-Domingue, the black freedman Toussaint Louverture emerged as a prominent leader in the 1791-93 insurrection and may have been one of its organizers. Less well known are the Maracaibo militia lieutenant Francisco Pirela; manservant Alexis Casimir, who played a shadowy role in the Martinique rebellion in 1789; and the black artillery sergeant who provided weapons for the Cartagena conspiracy of 1799.

Such figures generally lived close to the slave population and had enslaved family members. They tended to be black rather than of mixed descent, and to have little stake in slaveholding. ${ }^{19}$ In Brazil and Cuba, African ethnicity seems to have been an important variable, with freedmen and slaves from the same parts of Africa combining in rebellion. In contrast, the free men of colour who dominated or participated in multi-class rebellions, or who revolted in their own interest, tended to be slaveholders of mixed racial descent, as in the Grenada, St. Vincent, and Dominica uprisings of 1795, Francisco Morales's conspiracy of the same year in Cuba, and the 1798 Tailors' rebellion in Brazil (Geggus 1989:109-11). Free black and mulatto artisans played the most prominent roles in Cuba's Ladder conspiracy but, as a group, the former were regarded as the more radical and committed (Paquette 1988:241-2, 251-7). Slave rebellions and conspiracies influenced by the French and Haitian revolutions and, to a lesser degree, those influenced by abolitionist rumours tended to be associated with the presence of free people of colour. They no doubt had a wider awareness of external events than did the enslaved because of their much greater literacy and mobility.

Notwithstanding this widespread participation of free coloured individuals in slave resistance, free men of colour almost every-

18 Free men of colour played a similar role in Cuba's 1843 conspiracy (Paquette 1988:237-8, 242-3).

19 However, see Geggus 1997b:41 n96. Pirela was a pardo, of mixed racial descent, although wrongly identified as black in Dominguez 1980:159. Vesey's identity is also unclear (Morgan 2002:161-2). Chirinos was born free to an Indian mother, but his father, wife, and children were slaves. So were Toussaint Louverture's (Geggus 2007). Vesey's children were also slaves. 
where played an even more prominent role in the suppression of slave rebellions as part of local militia forces. In some instances, such as the Maracaibo, Cartagena, and Aponte conspiracies, pardo militiamen were responsible for their betrayal.

\section{CONCLUSION: REBELLION AND EMANCIPATION}

Despite the uniquely rapid growth of the U.S. slave population, slavery was a declining institution in the Americas by the end of the Age of Revolution in 1848. It had been abolished in the colonies of Britain, France, and Denmark, and the Atlantic slave trade was everywhere illegal, surviving only in Brazil and Cuba. How far, if at all, this decline was due to the wave of slave resistance discussed above remains a controversial topic (Drescher and Emmer 2010).

The massive Saint-Domingue slave revolt of 1791 was clearly the main factor in ending slavery in Saint-Domingue in 1793, and (until Bonaparte restored it in 1802) in Guadeloupe and Guyane in 1794. Even there, however, the outbreak of the European war in 1793 and the fortuitous presence of the abolitionist Commissaire Sonthonax were vital parts of the process. Rather less certain is whether the Haitian Revolution contributed to the abolition of the British slave trade in 1807 and to slave emancipation in Britain's colonies in 1833. If fear of future rebellions has been exaggerated as a causative factor, the revolution was surely important in allowing British politicians to vote their consciences by destroying France as a commercial rival (Geggus 2010). Similarly, Simón Bolívar's efforts to end slavery in Venezuela were in some measure a response to his military difficulties and his Enlightenment sensibility, but they could scarcely have been made without the Haitian assistance that revived his military campaign in 1816 (Verna 1969:87-298).

The British antislavery campaign that climaxed in 1833 evidently followed a metropolitan timetable, but many historians have argued that the major uprisings in Jamaica (1831) and Demerara (1823) catalysed its development. Whereas in the past they tended to stress metropolitan dread of continuing rebellions or repulsion at the planter class's brutal reaction to them, more recently they have emphasized the way the insurgents' discipline and restraint increased sympathy for their cause. ${ }^{20}$ Historians of Brazil still sharply disagree whether slave resistance in the late 1840 s contributed to the closure of that country's slave trade (Needell 2001, 2006:377). 
The Age of Revolution ended with two clear-cut cases, in Martinique and St. Croix, where slave rebellions made a definite contribution to the emancipation process. The rebellions were not, strictly speaking, causal factors since the decision to abolish slavery already had been taken and was the cause of the insurrections, but they did determine its timing. The mass invasion of the town of St. Pierre in May 1848 and the fighting it gave rise to in northern Martinique caused the governor to immediately declare slavery abolished. This brought forward by some three months the emancipation decreed in Paris by the new revolutionary government (Butel 2002:291-4). The declaration had immediate repercussions not only in the other French colonies but also those of Denmark. The Danish government had announced the previous year it would end slavery in 1859, but a massive rising of slaves on St. Croix in July 1848 shortened the process by eleven years (Hall 1992:208-11).

Several themes that characterize slave resistance in the Age of Revolution can be found in the two rebellions on Curaçao which, remarkably, were among the largest of this turbulent period. They were among the most closely associated with both the French and Haitian revolutions and they demonstrate the inspirational effect that foreign antislavery measures had on enslaved populations. They further provide evidence of the adoption of new, non-violent tactics. However, the Curaçao rebellions cannot be included in the small group that hastened the end of slavery, for which any surviving participants had to wait more than sixty years.

APPENDIX. SLAVE REBELLIONS AND CONSPIRACIES, $1776-1848$

Conspiracy/Revolt

1776

$\begin{array}{lcc}\begin{array}{l}\text { July, Jamaica } \\ \text { executed }\end{array} & \text { C } & \text { Hanover parish. } 30 \text { slaves } \\ \begin{array}{l}\text { July, North Carolina } \\ 1778\end{array} & \text { C? } & \text { Beaufort and other counties } \\ \begin{array}{l}\text { Easter, St. Kitts } \\ 1779\end{array} & \text { C } & \text { African and creole slaves } \\ \text { November, Peru } & \text { R } & 1 \text { plantation, 1 soldier killed } \\ \begin{array}{l}1784 \\ \text { Jamaica }\end{array} & \text { C } & \text { St. Mary's. Led by slave driver }\end{array}$


Jamaica

1789

June, Brazil

August, Martinique

Demerara

1790

January, Cuba

April, Guadeloupe

Spring? Venezuela

May, Tortola

Oct.-Dec., Martinique

1791

January, St. Lucia

January, Dominica

Mid-Jan., Dominica

January, St. Domingue

May, Guadeloupe

June/July, St. Domingue

July, Louisiana

August, Marie Galante

Aug./Nov., St. Domingue

Nov./Dec. Jamaica

1792

Saint-Domingue

1793

March, Sto. Domingo

April, Guadeloupe
R St. George's. 1 plantation, newly arrived Africans.

R Bahia. 50 slaves, 1 plantation, 1 white killed

R St. Pierre district. 3-400 slaves

R 1 plantation. Widespread conspiracy

R 1 plantation

R? Petit Bourg, etc. 100+ punished

$\mathrm{R} \quad 1$ plantation, 1 overseer killed

$\mathrm{R} \quad 1$ plantation, 2 slaves executed

$\mathrm{R} \quad$ West coast. Pillage and killing

C Soufrière. 1 plantation

$\mathrm{R}$ Work stoppage/desertion/ confrontation

R Free coloured leader. 1 white killed

C Port Salut. 200 slaves

C? Ste. Anne. Led by mulatto slave

$\mathrm{R} \quad$ Separate revolts on 3 estates, Cul de Sac

C Pointe Coupée. 17 slaves arrested

C Saint-Domingue. Free coloured hanged

R North Province. 100,000+ involved

C? $\quad$ North coast

R Revolt spreads beyond North. $1,000 \mathrm{~s}$

C Hinche. 19 arrested. No executions

R Trois Rivières. 200. 20 whites killed 


April, Guadeloupe
April, Guadeloupe
August, Guadeloupe
St. Lucia
1794
February, Martinique
1795
January, Curaçao
early, Santo Domingo
April, Louisiana
May, Bahamas
May, Venezuela
July, Cuba
July? Puerto Rico
August, Curaçao

Demerara

Aruba

Argentina

Trinidad

Cuba

1796

Feb.-April, Louisiana

May, Cuba

Oct., Santo Domingo

1797
C Baillif. 5 death sentences

C Basse-Terre region. 14 punished

R Ste. Anne. 1,000? slaves and freemen

$\mathrm{R}$

R Ste. Luce. During British invasion

R Santa Katarina. 1 plantation

C $\quad$ Samaná. 7 blacks, 3 French whites

C Pointe Coupée. 23 slaves executed

C Nassau. Francophone slaves

R Coro. 300 slaves and free blacks

R Puerto Principe. 15 slaves

R? Aguadilla. A few slaves

R 2,000 slaves? 29 slaves exe cuted

R Cooperation with maroon attacks

R 30 slaves, apparent Haitian inspiration

R? Buenos Aires. 3-day strike

C? 2 conspiracies in south and north

C Bayamo

C Pointe Coupée, German

Coast. 3 plots?

C Puerto Príncipe. 5 'French' slaves

R Boca Nigua. 100 slaves 7 executed

C Nassau. 'French' slaves.

5 executed 
1798

January, Venezuela

June, Cuba

July, Cuba

October, Cuba

Cuba

Cuba

1799

April, New Granada

May, Venezuela

1800

August, Virginia

September, Curaçao

1801

December, Tobago

1802

Jan.-April, Virginia

May, North Carolina

June, Cuba

1803

February, Cuba

June, Jamaica

1804

Demerara

South Carolina

1805

Cuba

April, North Carolina

December, Trinidad
C Carúpano/Cumaná. African slaves

R Puerto Principe. 20 slaves punished

C Trinidad. 2 slaves hanged; 8 deported

R Guines. 23 slaves on 1 estate

C Mariel

C Santa Cruz

C Cartagena. 'French' slaves, freemen

C Maracaibo. French and local freemen

C Richmond. 25 executed

$\mathrm{R} \quad$ Large multi-class rising

C 7 or 16 estates. 7 slaves executed

C Norfolk, etc. 25 slaves executed

C? $\quad 11$ slaves executed in a dozen counties

C Managua

C Río Hondo

C Kingston. 2 executed

C? Igbo and Akan friendly societies

C St. Peter's. 10 or 12 slaves executed

C Bayamo. English-speaking slaves

C Wayne County, etc., 20 arrested, 5 executed

C? 4 slaves executed 
1806

Cuba

Jamaica

C plantations near Havana

Puerto Rico

C St. George's. 1 slave executed

R Humacao. Slaves attack guard house

1807

May, Brazil

C Salvador/Reconcavo. Hausa leaders

September, Jamaica

R St. George

December, Demerara

C 20 slaves arrested. 9 executed 1808

December, Brazil

R Bahia. Several 100s

1809

Cuba

January, Brazil

March, Jamaica

Upper Peru

1810

February, Brazil

1811

January, Louisiana

Sept., Martinique

1811-13, Venezuela

1812

Cuba

January, Puerto Rico

C Puerto Príncipe

R Salvador/Reconcavo. 400 Africans

C Kingston. 2 executed

C Santa Cruz. Slaves and Indians

R Salvador

R German Coast. $400<500$ slaves. About 90 killed

R St. Pierre, 15 executed

R Central region. Widespread, encouraged by royalists

January, Cuba

February, Cuba

March, Cuba

C Centered on Havana. Wide-

spread

C? Widespread. 16 punished

R Puerto Principe. 8 hanged;

73 whipped

C Bayamo. 5 slaves jailed

C? Holguín. 1 slave executed

March, Cuba

R Guanabo. 1 estate

August, Louisiana

C New Orleans. 1 white executed

August, St. Domingo

1814

$\mathrm{R} \quad$ Eastern region. 3 executed

February, Brazil

R Salvador/Itapoam. 13 whites and 56 slaves killed 
2 Slave rebellion during the Age of Revolution

March, Brazil

1815

December, Jamaica

December, Brazil

1816

Jan.-July, S. Carolina

February, Brazil,

February, Virginia

April, Barbados

1817

Cuba

1819

May, Georgia

1820

March, Florida

June, Cuba

August, Cuba

Belize

1821

July, Puerto Rico

1822

February, Brazil

May, Cuba

June, Brazil

Sept., Puerto Rico

December, Brazil

South Carolina

October, Martinique
R Bahia

C St. Elizabeth. 250 Africans.

1 hanged

C Alagoas

C Camden, church-based. 6 slaves executed

R Bahia, Santo Amaro etc. Lasted 4 days

C Spotsylvania County. White leader, 6 slaves executed

$\mathrm{R}+4,000,120$ slaves killed, 144 executed

R 1 coffee plantation

C Augusta

R Jamaican slaves newly arrived

R Montalvo and Armonía plantations

R La Esperanza and La Concepción plantations

R New River. +100 slaves

C Bayamón. 2 slaves executed

R Bahia, São Mateus. Small revolt

R Mariel

$\mathrm{R} \quad$ Itaparicá. Small revolt

C Naguabo. 2 slaves executed

$\mathrm{R} \quad$ Bahia. +50 slaves killed. Portuguese instigated

C? Charleston. Denmark Vesey, 35 executed

R Carbet. 2 plantations, several whites killed 
1823

Tortola

August, Demerara

December, Jamaica 1824

February, Jamaica 1825

June-Aug., Cuba

1826

Cuba

May? Maryland

July, Puerto Rico

August, Brazil

September, Ohio R.

December, Brazil

1827

January, Cuba

February, Brazil

March, Brazil

September, Brazil

1828

Cuba

March, Brazil

April, Brazil

June, Brazil

Dec., Puerto Rico

December, Brazil

1829

March, Louisiana

April, South Carolina
R 1 plantation

$\mathrm{R}<12,000$ slaves, c220 slaves

killed, 33 executed

C Hanover, etc. 12 slaves executed

C St. George. 6 slaves hanged

R Matanzas. Revolts on 20 estates, 500 slaves

$\mathrm{R} \quad$ Western region. 1 plantation

$\mathrm{R} \quad 29$ slaves on ship, killed 2 whites

C Ponce. 20 slaves executed

$\mathrm{R} \quad$ Cachoeira

R $\quad 77$ slaves in transit, killed 5 whites

C Salvador/Reconcavo, centered on Yoruba quilombo

R Tentativa coffee plantation. 57 slaves

C Maranhão. Emancipation rumor, half-dozen estates

R Cachoeira. 3 plantations, 30 slaves arrested

R Sergipe. 10 plantations, mainly Yoruba. $<18$ slaves killed

$\mathrm{R} \quad$ Western region. 1 plantation

R Pirajá, Yoruba. 20 slaves killed

$\mathrm{R} \quad$ Cachoeira. 2 revolts

R Ilheus

C Guayama. Small, no executions

R Santo Amaro

R 2 slaves executed

C Georgetown 
August, Kentucky

October, Brazil

1830

April, New Orleans

April, Brazil

April, Tortola

June, Bahamas

July, Cuba

October, Louisiana

Brazil

1831

Cuba

Martinique

August, Virginia

September, Tortola

December, Tennessee

December, Jamaica

1832

May, Puerto Rico

1833

Jan., Puerto Rico

August, Cuba

1835

January, Brazil,

June, Cuba

July, Cuba

1836

Suriname

1837

June, Cuba

R 90 slaves in transit, 6 executed, 2 whites killed

R Reconcavo. 3 plantations, 3 killed

C 2 slaves executed

R Salvador. +120 slaves

R 1 plantation

R Exuma

R Guamacaro. 1 plantation

C Plaquemines. 100 slaves

R Salvador. +100 slaves; Yoruba. +50 killed

$\mathrm{R} \quad$ Western region. 1 plantation

C St. Pierre

R Southampton Co. 77 slaves, 57 whites killed

C widespread

C Fayetteville

R $\quad 18<60,000$ slaves, 540 slaves killed/executed

R Vega Baja. 1 plantation

C Ponce. 1 plantation

R Cafetal Salvador, Guanajay. 300 slaves, 53 slaves killed

R Salvador. 300 slaves/freedmen, 50 killed, 5 executed

R Matanzas. 3 plantations, 130 slaves

R Aguacate. 1 estate, 3 whites killed, 11 rebels commit suicide

C Coronie. 1 plantation, shaman leader

R La Sonora sugar estate. No whites killed, 3 slaves executed 


\begin{tabular}{|c|c|c|}
\hline August? Cuba & $\mathrm{C}$ & Guantánamo region \\
\hline October, Louisiana & C & $\begin{array}{l}\text { Rapides parish. } 50<60 \text { slaves, } \\
9 \text { slaves, } 3 \text { freemen executed }\end{array}$ \\
\hline \multicolumn{3}{|l|}{1838} \\
\hline Cuba, January & $\mathrm{R}$ & $\begin{array}{l}\text { Trinidad region. } 52 \text { Gangá } \\
\text { slaves, } 12 \text { shot }\end{array}$ \\
\hline Cuba, April & $\mathrm{R}$ & $\begin{array}{l}\text { Trinidad region. } 1 \text { white killed, } \\
5 \text { slaves executed }\end{array}$ \\
\hline $\begin{array}{l}\text { November, Brazil } \\
1839\end{array}$ & $\mathrm{R}$ & Vassouras. 300 slaves \\
\hline March, Cuba & $\mathrm{R}$ & $\begin{array}{l}\text { Matanzas. } 1 \text { plantation, Yoruba } \\
\text { slaves }\end{array}$ \\
\hline Cuba & $\mathrm{R}$ & $\begin{array}{l}\text { Matanzas. Revolts on several } \\
\text { other plantations }\end{array}$ \\
\hline \multicolumn{3}{|l|}{1840} \\
\hline June, Cuba & $\mathrm{R}$ & $\begin{array}{l}\text { Güines, Delgado estate. } 3 \text { slaves } \\
\text { killed }\end{array}$ \\
\hline July, Cuba & $\mathrm{R}$ & $\begin{array}{l}\text { Empresa plantation. }+40 \text { Yor- } \\
\text { uba slaves, } 2 \text { whites killed }\end{array}$ \\
\hline Sept./Oct., Louisiana & $\mathrm{C}$ & $\begin{array}{l}7 \text { parishes. } 100 \text { s, dozens } \\
\text { executed }\end{array}$ \\
\hline Sept., Puerto Rico & C & $\begin{array}{l}\text { Guayanilla. } 32 \text { punished, no } \\
\text { executions }\end{array}$ \\
\hline $\begin{array}{l}\text { October, Maryland } \\
1840 \mathrm{~s}\end{array}$ & $\mathrm{R}$ & 1 plantation, 1 white wounded \\
\hline Brazil & C & $\begin{array}{l}\text { Vassouras. 'Repeated abortive } \\
\text { uprisings' }\end{array}$ \\
\hline
\end{tabular}

1841

February, Georgia

C Augusta. 1 execution

Oct/Dec., Puerto Rico

C Ponce. 7 slaves executed 1842

July, Cuba

R La Arratía sugar estate. 42 slaves, 5 executed

1843

March, Puerto Rico

R Toa Baja. 5 soldiers killed, 8 slaves executed

March, Cuba

R Matanzas. 465 slaves, 128 killed,

May, Cuba lasted 2 days

R Sabanilla. 2 sugar estates 


\begin{tabular}{|c|c|c|}
\hline June, Cuba & $\mathrm{R}$ & $\begin{array}{l}\text { Sabanilla and Guamacaro. } \\
+300 \text { slaves }\end{array}$ \\
\hline November, Cuba & $\mathrm{R}$ & $\begin{array}{l}\text { Matanzas. } 66 \text { insurgents killed/ } \\
\text { executed }\end{array}$ \\
\hline December, Cuba & $\mathrm{C}$ & Matanzas. 17 slaves executed \\
\hline December, Cuba & $\mathrm{C}$ & $\begin{array}{l}\text { Multi-class, widespread, } \\
+1,800 \text { punished }\end{array}$ \\
\hline \multicolumn{3}{|l|}{1845} \\
\hline July, Maryland & $\mathrm{R}$ & $\begin{array}{l}75 \text { armed slaves, attempted } \\
\text { escape, battle, } 1 \text { executed }\end{array}$ \\
\hline \multicolumn{3}{|l|}{1848} \\
\hline May, Martinique & $\mathrm{R}$ & $\begin{array}{l}\text { St. Pierre, Prêcheur. 1,000s, } \\
58 \text { deaths, some arson }\end{array}$ \\
\hline July, St. Croix & $\mathrm{R}$ & $\begin{array}{l}8,000 \text { slaves, some property } \\
\text { damage, no deaths }\end{array}$ \\
\hline July, Puerto Rico & $\mathrm{C}$ & $\begin{array}{l}\text { Ponce. } 21 \text { slaves punished, } \\
3 \text { executed }\end{array}$ \\
\hline August, Puerto Rico & $\mathrm{C}$ & $\begin{array}{l}\text { Vega Baja. } 3 \text { slaves punished, } \\
1 \text { executed }\end{array}$ \\
\hline July-Aug., Brazil & C & Paraíba. 50 slaves \\
\hline August, Kentucky & $\mathrm{R}$ & $\begin{array}{l}75 \text { armed slaves, attempted } \\
\text { escape, battle, } 3 \text { executed }\end{array}$ \\
\hline
\end{tabular}

MAIN SOURCES

Geggus 1997b:46-50 (most Greater Caribbean items, 1789-1815); Aptheker 1943 (most U.S. items); Kápsoli Escudero 1975:66-71, 135 (Peru); VásquezMachicado 1988, VII:617-20 (Upper Peru); Oostindie this volume (Aruba, Curaçao); Egerton 1993 (Virginia); Crow 1980:97 (North Carolina 1802); Synnott 1976 and Craton 1982 (British Caribbean); Lynch 1973:197204 (Venezuela); Ferrer 2009:228, Barcia 2008:25-48, Childs 2006:12054, García 2003:34-9, Tardieu 2003:101-15, and Paquette 1988:70-1, 293 (nineteenth-century Cuba); Boyer-Peyreleau 1823, III:421 (Martinique 1822); Röhrig Assunção 1999:23 (Maranhão); Schwartz 1986:468-88, and Reis 1988:111-14 (Bahia); Stein 1957:145 (Vassouras); Baralt 1982 (Puerto Rico); Hall 1992:208-11 (St. Croix). 


\section{| David Geggus}

BIBLIOGRAPHY

Aizpurua, Ramón

1988 'La insurrección de los negros de la Serranía de Coro de 1795: Una revisión necesaria', Boletín de la Academia Nacional de la Historia 283:705-23.

Aptheker, Herbert

1943 American negro slave revolts. New York: Columbia University Press.

Baralt, Guillermo

1982 Esclavos rebeldes. Río Piedras: Huracán.

Barcia, Manuel

2008 Seeds of insurrection: Domination and resistance on western Cuban plantations, 1808-1848. Baton Rouge: Louisiana State University Press.

Barrow, John

1806 A voyage to Cochin China. London: T. Cadell.

Benjamin, Thomas

2009 The Atlantic world: Europeans, Africans, Indians and their shared history. Cambridge: Cambridge University Press.

Boyer-Peyreleau, Eugène-Edouard

1823 Les Antilles françaises, particulièrement la Guadeloupe, 1823, III:421 [Martinique 1822]. Paris: Brissot-Thivars.

Brereton, Bridget

2006 Haiti and the Haitian Revolution in the political discourse of nineteenth-century Trinidad. In: Martin Munro, Elizabeth Walcott-Hackshaw (eds), Reinterpreting the Haitian Revolution and its cultural aftershocks, pp.123-49. Mona: University of the West Indies Press.

Brito Figueroa, Federico

$1961 \quad$ Las insurrecciones de los esclavos negros en la sociedad colonial venezolana. Caracas: Cantaclaro.

1985 El problema tierra y esclavos en la historia de Venezuela. Caracas: Ediciones de la Biblioteca, Universidad Central de Venezuela.

Burton, Richard D.E.

1997

Afro-Creole: Power, opposition, and play in the Caribbean. Ithaca: Cornell University Press.

Butel, Paul

2002

Histoire des Antilles françaises, XVIIe-XXe siècle. Paris: Perrin. 
Childs, Matt

2006

The 1812 Aponte Rebellion in Cuba and the struggle against Atlantic slavery. Chapel Hill: University of North Carolina Press.

Craton, Michael

1979

'Proto-peasant revolts? The late slave rebellions in the British West Indies, 1816-1832', Past and Present 85:99-125.

1980 'The passion to exist: Slave rebellions in the British West Indies', Journal of Caribbean History 13:1-20.

1982 Testing the chains: Resistance to slavery in the British West Indies. Ithaca: Cornell University Press.

Crow, Jeffrey

1980 'Slave rebelliousness and social conflict in North Carolina', William and Mary Quarterly 38:79-102.

Debien, Gabriel and Pierre Pluchon

1978 'Un plan d'invasion de la Jamaïque', Revue de la Société Haïtienne d'Histoire et de Géographie 36:3-72.

1997 Documentos de la insurrección de José Leonardo Chirino. Vol. 2. Caracas: Fundación Historia y Comunicación.

Dominguez, Jorge I.

1980 Insurrection or loyalty: The breakdown of the Spanish American empire. Cambridge, MA.: Harvard University Press.

Drescher, Seymour and Pieter C. Emmer

$2010 \quad$ Who abolished slavery? Slave revolts and abolitionism: A debate with João Pedro Marques. New York: Berghahn.

Edsel, Carlos

1989 'Trois mulâtres de Curaçao, chantres de la liberté', in: Michel Martin and Alain Yacou (eds), De la révolution française aux révolutions créoles et nègres, pp. 61-8. Paris: Editions Caribéennes.

Egerton, Douglas

Gabriel's rebellion: The Virginia slave conspiracies of 1800 and 1802. Chapel Hill: University of North Carolina Press.

Engerman, Stanley L. and Barry W. Higman

'The demographic structure of the Caribbean slave societies in the eighteenth and nineteenth centuries', in: Franklin Knight (ed.), General History of the Caribbean. Vol. 3, pp. 45-104. London: Macmillan.

Ferrer, Ada

2008 'Talk about Haiti: The archive and the Atlantic's Haitian Revolution', in: Doris Garraway (ed.), Tree of liberty: Cul- 
tural legacies of the Haitian Revolution in the Atlantic world, pp. 21-40. Charlottesville: University of Virginia Press.

2009

'Speaking of Haiti: Slavery, revolution, and freedom in Cuban slave testimony', in: David Geggus and Norman Fiering (eds), The world of the Haitian Revolution, pp. 223-47. Bloomington: University of Indiana Press.

Fischer, Sibylle

2004

Modernity disavowed: Haiti and the cultures of slavery in the Age of Revolution. Durham: Duke University Press.

García, Gloria

$2003 \quad$ Conspiraciones y revueltas: La actividad política de los negros en Cuba, 1790-1845. Santiago de Cuba: Editorial Oriente.

Geggus, David Patrick

1987 'The enigma of Jamaica in the 1790s: New light on the causes of slave rebellions', William and Mary Quarterly 44(2):274-99.

'The French and Haitian Revolutions, and resistance to slavery in the Americas', Revue Française d'Histoire d'OutreMer 232-3:107-24.

'Esclaves et gens de couleur libres de la Martinique pendant l'époque révolutionnaire et napoléonienne: Trois moments de résistance', Revue Historique 295:105-32.

1997a 'Slave resistance in the Spanish Caribbean in the 1790s', in: David Barry Gaspar and David Patrick Geggus (eds), A turbulent time: The French Revolution and the Greater Caribbean, pp. 131-55. Bloomington: Indiana University Press.

1997b 'Slavery, war, and revolution in the Greater Caribbean, 17891815', in: David Barry Gaspar and David Patrick Geggus (eds), A turbulent time: The French Revolution and the Greater Caribbean, pp. 1-50. Bloomington: Indiana University Press.

2001 'Toussaint Louverture et l'abolition de l'esclavage à SaintDomingue', in: Liliane Chauleau (ed.) Les abolitions dans les Amérique, pp. 109-16. Fort de France: Société des Amis des Archives.

2002 Haitian revolutionary studies. Bloomington: Indiana University Press.

2003 'The influence of the Haitian Revolution on blacks in Latin America and the Caribbean', in: Nancy Naro (ed.), Blacks, coloureds and national identity in nineteenth-century Latin America, pp. 38-59. London: Institute of Latin American Studies. 
2006

'Print culture and the Haitian Revolution: The written and the spoken word', Proceedings of the American Antiquarian Society 2:297-314.

2007 'Toussaint Louverture and the Haitian Revolution', in: R. William Weisberger, Dennis P. Hupchick and David L. Anderson (eds), Profiles of revolutionaries in Atlantic History, 1750-1850, pp. 115-35. New York: Columbia University Press.

2009 'Saint-Domingue on the eve of the Haitian Revolution', in: David Patrick Geggus and Norman Fiering (eds), The world of the Haitian Revolution, pp. 3-20. Bloomington: University of Indiana Press.

2010 'Slave resistance and emancipation: The case of SaintDomingue', in: Seymour Drescher and Pieter Emmer (eds), Who abolished slavery? pp. 112-19. New York: Berghahn Books.

Genovese, Eugene

1979 From rebellion to revolution: Afro-American slave revolts in the making of the modern world. Baton Rouge: Louisiana State University Press.

1986 'Herbert Aptheker's achievement and our responsibility', in: Gary Okihiro (ed.), In resistance: Studies in African, Caribbean, and Afro-American history, pp. 21-31. Amherst: University of Massachusetts Press.

Goslinga, Cornelis Ch.

1990 The Dutch in the Caribbean and in Surinam 1791/5-1942. Assen: Van Gorcum.

Hall, Neville

1992 Slave society in the Danish West Indies. Mona: University of the West Indies Press.

Hartog, Johannes

1961 Curaçao: Van kolonie tot autonomie. Vol. 1:325-27. Oranjestad: De Wit.

Helg, Aline

2001 'A fragmented majority: Free "of all colors", Indians, and slaves in Caribbean Colombia during the Haitian Revolution', in: David Geggus (ed.), The impact of the Haitian Revolution in the Atlantic world, pp. 157-75. Columbia: University of South Carolina Press.

Johnson, Michael P.

2001 'Denmark Vesey and his co-conspirators', William and Mary Quarterly 58:915-76. 


\section{| David Geggus}

Kápsoli Escudero, Wilfredo

1975 Sublevaciones de esclavos en el Perú, siglo XVIII. Lima: Universidad Ricardo Palma.

Langley, Lester

1996

The Americas in the Age of Revolution, 1750-1850. New Haven: Yale University Press.

Lynch, John

1973

The Spanish American Revolutions. London: Weidenfeld and Nicolson.

Maxwell, Kenneth

1973

Conflicts and conspiracies in Brazil and Portugal, 1750-1808. Cambridge: Cambridge University Press.

Moore, Barrington

1978

Injustice: The social bases of obedience and revolt. New York: M.E. Sharpe.

Morgan, Philip D.

2002 'Conspiracy scares’, William and Mary Quarterly 59(1):159-66.

Mott, Luiz

1982 'A revolução dos negros do Haiti e o Brasil', Mensario do Arquivo Nacional 13:3-10.

Needell, Jeffrey

2001

'The abolition of the Brazilian slave trade in 1850: Historiography, slave agency and statesmanship', Journal of Latin American Studies 33:681-711.

2006

The Party of Order: The conservatives, the state and slavery in the Brazilian monarchy, 1831-1871. Stanford: Stanford University Press.

Palacios, Roberto

1983 'Ansia de libertad', Lantèrnu 1(1):20-7.

Paquette, Robert

$1988 \quad$ Sugar is made with blood: The conspiracy of La Escalera and the conflict between empires over slavery in Cuba. Middletown: Wesleyan University Press.

1997

'Revolutionary Saint-Domingue in the making of Territorial Louisiana', in: Barry Gaspar and David Patrick Geggus (eds), A turbulent time: The French Revolution and the Greater Caribbean, pp. 204-25. Bloomington: Indiana University Press.

Pauléus Sannon, Horace

1920

Histoire de Toussaint-Louverture. Port-au-Prince: A.A. Héraux. 
Quarles, Benjamin

1961

The negro in the American Revolution. Chapel Hill: University of North Carolina Press.

Reis, João

1988

'Slave resistance in Brazil: Bahia, 1807-1835', Luso-Brazilian Review 25:111-14.

1993 Slave rebellion in Brazil: The muslim uprising of 1835 in Bahia. Baltimore: Johns Hopkins University Press.

Reis, João and Flavio Gomes

2009 'Repercussions of the Haitian Revolution in Brazil, 17911850', in: David Patrick Geggus and Norman Fiering (eds), The world of the Haitian Revolution, pp. 284-313. Bloomington: University of Indiana Press.

Rivas, Pedro Gil, Luis Dovale Prado and Lidia L. Bello

1996 La insurrección de los negros de la Serranía Coriana, 10 de Mayo de 1795: Notas para la discussion. Caracas: Universidad Central de Venezuela.

Röhrig Assunção, Matthias

1999 'Elite politics and popular rebellion in the construction of post-colonial order: The case of Maranhão, Brazil, 18201841', Journal of Latin American Studies 31:1-38.

Schama, Simon

2005

Rough crossing: Britain, the slaves and the American Revolution. London: BBC Books.

Schwartz, Stuart

1986 Sugar plantations in the formation of Brazilian society: Bahia, 1550-1835. Cambridge: Cambridge University Press.

Scott, Julius S.

1986

The common wind: Currents of Afro-American communication in the era of the Haitian Revolution. PhD thesis, Duke University, Durham.

Sidbury, James

$1997 \quad$ Ploughshares into swords: Race, rebellion, and identity in Gabriel's

Virginia, 1730-1810. New York: Cambridge University Press. Stein, Stanley J.

1957 Vassouras, a Brazilian coffee county, 1850-1900. Cambridge, MA.: Harvard University Press.

Synnott, Anthony

1976 Slave revolts in the Caribbean. PhD thesis, University of London. 


\section{| David Geggus}

Tardieu, Jean-Pierre

2003 'Morir o dominar': En torno al reglamento de esclavos de Cuba (1841-1866). Iberoamericana: Madrid.

Vásquez-Machicado, Humberto and José Vásquez-Machicado

1988

'El alzamiento de Santa Cruz, 1809', in: Guillermo Ovando

Sanz and Alberto Vásquez, (eds), Obras completas de Humberto Vásquez-Machicado y José Vásquez-Machicado, pp. 617-20. La Paz: Don Bosco.

Verna, Paul

1969

Petión y Bolívar: Cuarenta años de relaciones haitiano-venezolanas. Caracas: Oficina Central de Información.

Yacou, Alain

1984

'Le projet des révoltes serviles de l'île de Cuba dans la première moitié du XIXe siècle', Revue du CERC 1 (1984):46-67. 